\title{
Communication for High-Performance
}

\author{
Atsuko Kaneko \\ Meiji University, Tokyo, Japan
}

\section{Introduction}

Communication skills are of great interest in the workplace and have been listed as the number one skill required for new graduates in Japan for 16 consecutive years (Keidanren, 2018). Communication, together with integrity, is regarded as an overwhelmingly important soft skill by the US executives as well (Robles, 2012). However, meanings of communication could be broad, and it is not straightforward when we try to define its domain.

We would agree that workplace communication has a different focus than general social communication. General communication mainly focuses on interpersonal relationships whereas workplace communication focuses on task completion as well as interpersonal relationship building. Even though both task completion and interpersonal relationship building are essential for high performance organizations, some managers seem to be more interested in tasks. Managers would even view "communication as a means to an end, something to be exploited in the service of organizational objectives after weighing the cost-benefit considerations" (Smeltzer, Glab, \& Golen, 1983).

Practically, managers would be interested in the desirable allocation between interpersonal relationship building and task completion. This article intends to introduce some perspectives on effective communication in a managerial context through

Received: Jul 30, 2020 Revised: Sep 27, 2020 Accepted: Sep 29, 2020

Corresponding author: Atsuko Kaneko

Izumi Campus Faculty Office Building 163, 1-9-1 Eifuku, Suginai-ku, Tokyo 168-8555, Japan

Tel: +81-3-5300-1266, E-mail: atsukokaneko@meiji.ac.jp

This is an Open Access article distributed under the terms of the Creative Commons Attribution Non-Commercial License (http://creativecommons.org/licenses/ by-nc/4.0/) which permits unrestricted non-commercial use, distribution, and reproduction in any medium, provided the original work is properly cited.

Copyright $\odot 2021$ Korean Association for Business Communication. reviewing some research on the communication that takes place in a high-performance team in Japan.

\section{Communication for Shared Goals}

Communication can be described as "the process of sharing meaning by transmitting messages through media such as words, behavior, or material artifacts and it is a complex process of linking up or sharing the perceptual fields of sender and receiver" (Deresky, 2017, pp. 150-151). Drucker (2008) described four characteristics of communication for the managerial context: perception of receivers; expectation of receivers; a burden on receivers; different from information. Drucker (2008) pointed out that receivers play a more important role than senders and that the receivers selectively understand messages consistent with their own expectations and perceptions of reality.

The process of communication is often modeled as an exchange of meaning through encoding, sending, receiving, and decoding, and messages are not always interpreted as intended as a result of noise. From a social constructivist viewpoint, however, meanings held by the sender and the receiver are different anyway because the realities of the communicators are simply different. Considering the fact that realities held by individuals are necessarily different, communicating messages perfectly as intended would be impossible.

Also, neither managers nor subordinates understand reality in a single right way. So, as Drucker (2008) pointed out, communication between managers and subordinates should primarily focus on discussing shared goals instead of competing on who knows "the truth." In a managerial context, all activities including communication, should serve a company's organizational goals. It may sound obvious to some readers, but it is not necessarily explicitly shared in some cultures. 


\section{Communication for High Performance in a Japanese Context}

Management communication focuses on examining how "managers" use language to "get work done with and through people" (Rogers, 2014), but the expression "through people" does not seem to fit in most Japanese contexts. The old definition of management is "getting things done through others" (Nakagawa, 2020). Some people may be uncomfortable with this understanding of the word, as it implies controlling others and moving them at will. A more personable understanding of this word may be "getting things done with others" (Nakagawa, 2020).

An emphasis on "we" in communication could also be observed in flatter organizational structures. As research on leadership has expanded from a focus on the leader to one on followers and the team as a whole, many scholars have been interested in effective team communication. For example, Wheelan (2016) noted that members of high-performance work teams spend between $70 \%$ and $80 \%$ of the time talking about goals, tasks, and supportive messages, and the team will be less successful if members talk too much about reminders such as social statements unrelated to work.

This seems in line with classic research conducted in Japan indicating that a high-performance team shared more messages related to task procedural information than formal relationship building messages such as greetings. Furukawa (2003) analyzed the content of comments from the electronic communication system of a sales department of a general electronics manufacturer in Tokyo and found four message categories: information exchange; work procedure and progress; supportive messages; greetings. On average, $35 \%$ was occupied by the information exchange category, $20 \%$ by work procedures, $20 \%$ by supportive messages, and $20 \%$ by greetings.

Contrasting the high-performance team and the low-performance team, the high-performance team exchanged more messages in the information exchange category (47\%) than low performance teams $(23 \%)$ while low performance team filled it with greetings (36\% in low-performance team versus $11 \%$ in high performance team) (Furukawa, 2003). This is important because they tend to emphasize co-existing in the physical workplace and spending time together without much verbal communication to support interpersonal relation building.

It should be also noted that hierarchy in organization still matters for effective communication in spite of the current trend toward flatter company structure. For example, in the Japanese context, Furukawa (2011) gave some examples of downward (supervisors to supervisees), upward (supervisees to supervisors), and horizontal communication. Downward com- munication includes setting goals, instruction of policies and procedures, guidance, arousing problems, feedback and evaluation; upward communication includes reporting progress and problems, inquiries about activities; and horizontal communication includes requests, confirmations, exchanges of opinions, consultations (Furukawa, 2011). All messages could be sent by any member regardless of hierarchical position, but if team members are ignorant of expected roles, there would be a risk of facing a threatening act, which would lead to low productivity.

\section{Conclusion}

Business communication within organizations should serve organizational goals taking care of both task completion and relationship building. It is essential to contextualize business communication in management activities integrating knowledge of communication, management, psychology, and language. The message construct of high-performance teams clarifying the context would be helpful for practical purposes.

\section{References}

Deresky, H. (2017). International management: Managing Across Borders and Cultures (9th ed.). Essex, UK: Pearson.

Drucker, P. F. (2008). Management: Tasks, responsibilities, practices (Y. Aruga Trans.). Tokyo, Japan: Nikkei BP.

Furukawa, H. (2003). Creating a core new edition. Tokyo, Japan: Nihon Nohritsu Management Center.

Furukawa, H. (2011). Organizational psychology. Tokyo, Japan: Baifukan.

Keidanren (Japan Business Federation, Nihon Keizai Dantai Rengoukai) (2018, November 22). 2018 survey of new graduate hiring. Retrieved from https://www.keidanren.or.jp/ policy/2018/110.pdf

Nakagawa, K. (2020, August 25). Fueki Ryuko no Keieigaku 5. Nihon Keizai Shimbun. Retrived from https://www.nikkei.com/ article/DGXMZO62978430U0A820C2SHE000/

Robles, M. M. (2012). Executive perceptions of the top 10 soft skills needed in today's workplace. Business Communication Quarterly, 75(4), 453-465.

Rogers, P. S. (2014). 12 Management communication: Getting work done through people. In V. Bhatia, \& S. Bremner (Eds.), The routledge handbook of language and professional communication (pp. 165-192). Abingdon, UK: Routledge.

Smeltzer, L. R., Glab, J., \& Golen, S. (1983). Managerial communication: The merging of business communication, organizational communication, and management. The Journal of Business Communication, 20(4), 71-78. 
